\title{
PENINGKATAN KOMPETENSI GURU DALAM PENYUSUNAN RENCANA PELAKSANAAN PEMBELAJARAN \\ KURIKULUM 2013 MELALUI PENDAMPINGAN
}

\author{
Cut Helma* \\ *Cut Helma, adalah Pengawas Sekolah Kota Lhokseumawe, Provinsi Aceh \\ Email: cuthelma7@gmail.com
}

\begin{abstract}
Abstrak:
Penelitian ini bertujuan untuk mendeskripsikan peningkatan kompetensi guru dalam penyusunan rencana pelaksanaan pembelajaran kurikulum 2013 melalui pendampingan di SMP binaan Kota Lhokseumawe tahun 2019. Penelitian ini dilaksanakan di sekolah binaan yang ada di kota Lhokseumawe yang dilaksanakan mulai dari bulan Januari sampai dengan Mei 2019. Subjek penelitian adalah guru-guru yang yang menjadi binaan peneliti sebanyak 20 orang guru. Metode yang digunakan dalam penelitian ini adalah metode Penelitian Tindakan Sekolah (PTS). Penelitian ini dilaksanakan dalam dua siklus. Setiap siklus teridiri dari tahap perencanaan, tahap pelaksanaan, tahap observasi dan tahap refleksi. Pendekatan yang digunakan dalam penelitian adalah pendekatan kualitatif. Data dalam penelitian diperoleh dari wawancara dan observasi guru menyusun Rencana Pelaksanaan Pembelajaran (RPP) Kurikulum 2013. Teknik analisis data dalam penelitian ini adalah dengan menggunakan persentase dan nilai ratarata. Hasil penelitian diketahui bahwa Jika ditinjau dari seluruh kategori yang dinilai pada siklus pertama nilai rata-rata komponen penyusunan RPP adalah $68,64 \%$. Sedangkan pada siklus kedua nilai rata-rata komponen penyusunan RPP $85,11 \%$. Peningkatan kompetensi guru dalam menyusun RPP dari siklus pertama adalah 16,47\%. Sehingga dapat disimpulkan bahwa melalui pendampingan dapat meningkatkan kompetensi guru dalam menyusun RPP kurikulum 2013 di SMP binaan Kota Lhokseumawe tahun 2019.
\end{abstract}

Kata Kunci: Kompetensi Guru, RPP, Kurikulum dan Pendampingan

\section{PENDAHULUAN}

Menurut Undang-Undang Nomor 20 tahun 2003 tentang Sistem Pendidikan Nasional menyatakan, "komponen-komponen sistem pendidikan yang bersifat sumber daya manusia dapat digolongkan menjadi tenaga pendidik dan pengelola satuan pendidikan (penilik, pengawas, peneliti dan pengembang pendidikan)". Guru, siswa, dan kurikulum adalah tiga komponen utama dalam sistem pendidikan nasional. Ketiga komponen pendidikan tersebut merupakan syarat mutlak dalam proses pendidikan di

Jurnal Serambi Ilmu. p-ISSN 1693-4849, e-ISSN 2549-2306

Journal of Scientific Information and Educational Creativity 
sekolah. Guru merupakan salah satu komponen yang mempunyai peranan penting, karena guru adalah pelaksana dalam kegiatan pembelajaran.

Berdasarkan kenyataan, begitu berat dan kompleksnya tugas serta peran guru tersebut, perlu diadakan supervisi atau pembinaan terhadap guru secara terus menerus untuk meningkatkan kinerjanya. Kinerja guru perlu ditingkatkan agar usaha membimbing siswa untuk belajar dapat berkembang. "Proses pengembangan kinerja guru terbentuk dan terjadi dalam kegiatan belajar mengajar di tempat mereka bekerja. Selain itu kinerja guru dipengaruhi oleh hasil pembinaan dan supervisi kepala sekolah dan pengawas" (Pidarta, 2003:3).

Pada pelaksanaan Kurikulum 2013 menuntut kemampuan baru pada guru untuk dapat mengelola proses pembelajaran secara efektif dan efisien. Tingkat produktivitas sekolah dalam memberikan pelayanan-pelayanan secara efisien kepada pengguna (siswa dan masyarakat) akan sangat tergantung pada kualitas guru yang terlibat langsung dalam proses pembelajaran dan keefektifan mereka dalam melaksanakan tanggung jawab individual dan kelompok.

Direktorat Pembinaan Pendidikan Dasar (2008:3) menyatakan bahwa: Kualitas pendidikan sangat ditentukan oleh kemampuan sekolah dalam mengelola proses pembelajaran, dan lebih khusus lagi adalah proses pembelajaran yang terjadi di kelas, mempunyai andil dalam menentukan kualitas pendidikan, konsekuensinya adalah guru harus mempersiapkan (merencanakan) segala sesuatu agar proses pembelajaran di kelas berjalan dengan efektif.

Hal ini berarti bahwa guru sebagai fasilitator dalam mengelola proses pembelajaran di kelas mempunyai andil dalam menentukan kualitas pendidikan. Konsekuensinya adalah guru harus mempersiapkan (merencanakan) segala sesuatu agar proses pembelajaran di kelas berjalan dengan efektif. Perencanaan pembelajaran merupakan langkah yang sangat penting sebelum pelaksanaan pembelajaran. Perencanaan yang matang diperlukan supaya pelaksanaan pembelajaran berjalan secara efektif. Perencanaan pembelajaran dituangkan ke dalam Rencana Pelaksanaan Pembelajaran (RPP) atau beberapa istilah lain seperti desain pembelajaran, skenario pembelajaran. RPP memuat KI, KD, indikator yang akan dicapai, materi yang akan dipelajari, langkah pembelajaran, media pembelajaran, dan sumber belajar serta penilaian.

Jurnal Serambi Ilmu. p-ISSN 1693-4849, e-ISSN 2549-2306 
Guru harus mampu berperan sebagai desainer (perencana), implementor (pelaksana), dan evaluator (penilai) kegiatan pembelajaran. Guru merupakan faktor yang paling dominan karena di tangan gurulah keberhasilan pembelajaran dapat dicapai. Kualitas mengajar guru secara langsung maupun tidak langsung dapat mempengaruhi kualitas pembelajaran pada umumnya.

RPP dikembangkan oleh guru pada satuan pendidikan. Guru pada satuan pendidikan berkewajiban menyusun RPP secara lengkap dan sistematis agar pembelajaran berlangsung secara interaktif, inspiratif, menyenangkan, menantang, memotivasi siswa untuk berpartisipasi aktif, serta memberikan ruang yang cukup bagi prakarsa, kreativitas, dan kemandirian sesuai dengan bakat, minat dan perkembangan fisik serta psikologis siswa.

Berdasarkan hasil observasi, masalah yang terjadi di lapangan masih ditemukan adanya guru (baik di sekolah negeri maupun swasta) yang tidak bisa memperlihatkan RPP yang dibuat dengan alasan ketinggalan di rumah dan masih ditemukan bagi guru yang sudah membuat RPP, adanya guru yang belum melengkapi komponen tujuan pembelajaran dan penilaian (soal, skor dan kunci jawaban), serta langkah-langkah kegiatan pembelajarannya masih dangkal. Soal, skor, dan kunci jawaban merupakan satu kesatuan yang tidak dapat dipisahkan. Pada komponen penilaian (penskoran dan kunci jawaban) sebagian besar guru tidak lengkap membuatnya dengan alasan sudah tahu dan ada di kepala. Sedangkan pada komponen tujuan pembelajaran, materi ajar, metode pembelajaran, dan sumber belajar sebagian besar guru sudah membuatnya.

Masalah yang lain yaitu sebagian besar guru khususnya di sekolah swasta belum mendapatkan pelatihan pengembangan RPP. Selama ini guru-guru yang mengajar di sekolah khususnya sekolah swasta juga sedikit/jarang mendapatkan kesempatan untuk mengikuti berbagai diklat peningkatan profesionalisme guru dibandingkan sekolah negeri. Hal ini menyebabkan banyak guru yang belum tahu dan memahami penyusunan/ pembuatan RPP secara baik/lengkap. Beberapa guru mengadopsi RPP orang lain. Hal ini peneliti ketahui pada saat mengadakan observasi ke sekolah binaan. Permasalahan tersebut berpengaruh besar terhadap pelaksanaan proses pembelajaran. Rencana Pelaksanaan Pembelajaran harus dibuat agar kegiatan pembelajaran berjalan sistematis 
dan mencapai tujuan pembelajaran. Tanpa Rencana Pelaksanaan Pembelajaran, biasanya pembelajaran menjadi tidak terarah. Oleh karena itu, guru harus mampu menyusun RPP dengan lengkap berdasarkan silabus yang disusunnya. Rencana Pelaksanaan Pembelajaran sangat penting bagi seorang guru karena merupakan acuan dalam melaksanakan proses pembelajaran.

Berdasarkan uraian di atas dapat dikatakan, bahwa RPP sangat besar pengaruhnya bagi guru dalam kegiatan belajar mengajar di sekolah. Sehubungan dengan itu, penulis selaku pengawas tertarik untuk mengadakan penelitian tindakan sekolah tentang yang berjudul "Peningkatan Kompetensi Guru dalam Penyusunan Rencana Pelaksanaan Pembelajaran Kurikulum 2013 melalui Pendampingan Di SMP Binaan Kota Lhokseumawe Tahun 2019”.

\section{Pengawas Sekolah}

Pengawas sekolah adalah salah satu tenaga pendidikan yang memiliki tugas untuk meningkatkan profesionalisme guru dan meningkatkan mutu pendidikan di sekolah. Sebelum diangkat menjadi pengawas sekolah, maka calon pengawas harus menjadi guru atau kepala sekolah terlebih dahulu. Dalam PP Nomor 19 Tahun 2005 pasal 39 ayat (2) menyatakan bahwa kriteria minimal untuk menjadi pengawas sekolah adalah berstatus sebagai guru sekurang-kurangnya 8 tahun atau kepala sekolah sekurang-kurangnya 4 tahun pada jenjang pendidikan yang sesuai dengan satuan pendidikan yang diawasi. Hal ini bertujuan agar pengawas sekolah mengetahui seluk beluk tentang pembelajaran dan pengelolaan sekolah karena salah satu tugas pengawas adalah melaksanakan pengawasan terhadap sekolah binaannya.

Jenjang jabatan pengawas sekolah diatur dalam Peraturan Menteri Pendayagunaan Aparatur Negara dan Reformasi Birokrasi nomor 21 tahun 2010 tentang Jabatan Funsional Pengawas Sekolah dan Angka Kreditnya pasal 13, yang menyebutkan bahwa jenjang jabatan pengawas dibagi menjadi tiga. Dimulai dari jenjang jabatan yang terendah sampai jenjang jabatan yang tertinggi yaitu pengawas muda dengan golongan III/c-III/d, pengawas madya dengan golongan IV/a-IVc, dan pengawas utama dengan golongan IV/d-IVe.

Mengacu pada SK Menpan nomor 118 tahun 1996 tentang jabatan fungsional pengawas dan angka kreditnya, Keputusan bersama Mendikbud nomor 03420/O/1996 
dan Kepala Badan Administrasi Kepegawaian Negara nomor 38 tahun 1996 tentang petunjuk pelaksanaan jabatan fungsional pengawas serta Keputusan Mendikbud nomor 020/U/1998 tentang petunjuk teknis pelaksanaan jabatan fungsional pengawas sekolah dan angka kreditnya, dapat dikemukakan tentang tugas pokok dan tanggung jawab pengawas sekolah yang meliputi: (1) Melaksanakan pengawasan penyelenggaraan pendidikan di sekolah sesuai dengan penugasannya pada TK, SD, SLB, SLTP dan SLTA. (2)Meningkatkan kualitas proses belajar-mengajar/bimbingan dan hasil prestasi belajar/bimbingan siswa dalam rangka mencapai tujuan pendidikan.

\section{Guru}

Secara etimologi (asal usul kata), istilah "Guru" berasal dari bahasa India yang artinya "orang yang mengajarkan tentang kelepasan dari sengsara" Shambuan, Republika, (Suparlan 2005:11). Kemudian Rabindranath Tagore (dalam Suparlan, 2005:11) menggunakan istilah Shanti Niketan atau rumah damai untuk tempat para guru mengamalkan tugas mulianya membangun spiritualitas anak-anak bangsa di India (spiritual intelligence).

UU Guru dan Dosen Republik Indonesia No.14 Tahun 2005 "Guru adalah pendidik profesional dengan tugas utama mendidik, mengajar, membimbing, mengarahkan, melatih, menilai, dan mengevaluasi peserta didik pada pendidikan anak usia dini jalur pendidikan formal, pendidikan dasar, dan pendidikan menengah".

Berdasarkan definisi di atas, dapat disimpulkan bahwa guru adalah tenaga pendidik yang profesional dengan tugas utama mendidik, mengajar, membimbing, mengarahkan, melatih, menilai dan mengevaluasi peserta didik, dan bertugas merencanakan dan melaksanakan proses pembelajaran.

\section{Standar Kompetensi Guru}

Depdiknas (2004:4) mengatakan bahwa kompetensi diartikan, "sebagai pengetahuan, keterampilan, dan nilai-nilai dasar yang direfleksikan dalam kebiasaan berpikir dan bertindak". "Secara sederhana kompetensi diartikan seperangkat kemampuan yang meliputi pengetahuan, sikap, nilai dan keterampilan yang harus 
dikuasai dan dimiliki seseorang dalam rangka melaksanakan tugas pokok, fungsi dan tanggung jawab pekerjaan dan/atau jabatan yang disandangnya" (Nana Sudjana 2009:1).

Nurhadi (2004:15) menyatakan bahwa kompetensi merupakan pengetahuan, keterampilan, dan nilai-nilai dasar yang direfleksikan dalam kebiasaan berpikir dan bertindak. Kompetensi diartikan sebagai pengetahuan, keterampilan, dan nilai-nilai dasar yang direfleksikan dalam kebiasaan berfikir dan bertindak (Suparlan, 2005).

Undang-Undang Guru dan Dosan No.14 Tahun 2005 Pasal 8 menyatakan bahwa guru wajib memiliki kualifikasi akademik, kompetensi, sertifikat pendidik, sehat jasmani dan rohani, serta memiliki kemampuan untuk mewujudkan tujuan pendidikan nasional. Dari rumusan di atas jelas disebutkan pemilikan kompetensi oleh setiap guru merupakan syarat yang mutlak harus dipenuhi oleh guru. Dengan demikian, kompetensi yang dimiliki oleh setiap guru akan menunjukkan kualitas guru yang sebenarnya.

Selanjutnya Pasal 10 menyebutkan empat kompetensi yang harus dimiliki oleh guru yakni (1) kompetensi pedagogik, (2) kompetensi kepribadian, (3) kompetensi sosial, dan (4) kompetensi profesional. Kompetensi tersebut akan terwujud dalam bentuk penguasaan pengetahuan, keterampilan, maupun sikap profesional dalam menjalankan fungsi sebagai guru.

Berdasarkan beberapa definisi di atas dapat disimpulkan standar kompetensi guru adalah suatu pernyataan tentang kriteria yang dipersyaratkan, ditetapkan dalam bentuk penguasaan perangkat kemampuan yang meliputi pengetahuan, sikap, nilai dan keterampilan bagi seorang tenaga kependidikan sehingga layak disebut kompeten.

\section{Tujuan dan Manfaat Standar Kompetensi Guru}

Depdiknas (2004: 4) tujuan adanya Standar Kompetensi Guru adalah sebagai jaminan dikuasainya tingkat kompetensi minimal oleh guru sehingga yang bersangkutan dapat melakukan tugasnya secara profesional, dapat dibina secara efektif dan efisien serta dapat melayani pihak yang berkepentingan terhadap proses pembelajaran, dengan sebaik-baiknya sesuai bidang tugasnya. Adapun manfaat disusunnya standar kompetensi guru adalah sebagai acuan pelaksanaan uji kompetensi, penyelenggaraan diklat, dan pembinaan, maupun acuan bagi pihak yang berkepentingan terhadap kompetensi guru untuk melakukan evaluasi, pengembangan bahan ajar dan sebagainya bagi tenaga kependidikan.

Jurnal Serambi Ilmu. p-ISSN 1693-4849, e-ISSN 2549-2306

Journal of Scientific Information and Educational Creativity 


\section{Rencana Pelaksanaan Pembelajaran}

Philip Combs (Kurniawati, 2009:66) menyatakan bahwa perencanaan program pembelajaran merupakan suatu penetapan yang memuat komponen-komponen pembelajaran secara sistematis. Analisis sistematis merupakan proses perkembangan pendidikan yang akan mencapai tujuan pendidikan agar lebih efektif dan efisien disusun secara logis, rasional, sesuai dengan kebutuhan siswa, sekolah, dan daerah (masyarakat). Perencanaan program pembelajaran adalah hasil pemikiran, berupa keputusan yang akan dilaksanakan. Selanjutnya Oemar Hakim (Kurniawati 2009:74) menyatakan, "bahwa perencanaan program pembelajaran pada hakekatnya merupakan perencanaan program jangka pendek untuk memperkirakan suatu proyeksi tentang sesuatu yang akan dilakukan dalam kegiatan pembelajaran".

Permendiknas No. 103 tahun 2014 menyatakan, "Rencana Pelaksanaan Pembelajaran (RPP) adalah rencana yang menggambarkan prosedur dan pengorganisasian pembelajaran untuk mencapai satu kompetensi dasar dalam beberapa pertemuan yang mengacu pada standar isi, standar kelulusan dan telah dijabarkan dalam silabus."

Berdasarkan pendapat di atas dapat disimpulkan bahwa perencanaan pembelajaran adalah suatu upaya menyusun perencanaan pembelajaran yang akan dilaksanakan dalam kegiatan pembelajaran untuk mencapai tujuan yang telah ditetapkan dalam kurikulum sesuai dengan kebutuhan siswa, sekolah, dan daerah.

\section{Komponen Rencana Pelaksanaan Pembelajaran}

Menurut Permendiknas No. 103 Tahun 2014, komponen RPP terdiri dari a). identitas mata pelajaran, (b) kompetensi inti, (c) kompetensi dasar, (d) indikator pencapaian kompetensi, (e) materi ajar, (f) alokasi waktu, (g) kegiatan pembelajaran dengan pendekatan saintific dan tematik integratif. (h) sumber belajar, (i) penilaian hasil belajar meliputi: soal, skor dan kunci jawaban. 


\section{Prinsip-prinsip Penyusunan RPP}

Permendiknas No. 103 Tahun 2014 menyatakan dalam menyusun rencana pelaksanaan pembelajaran harus memperhatikan prinsip-prinsip sebagai berikut: a) memperhatikan perbedaan individu peserta didik, b) mendorong partisipasi aktif peserta didik, c) mengembangkan budaya membaca dan menulis, d) memberikan umpan balik dan tindak lanjut, e) keterkaitan dan keterpaduan, f) menerapkan teknologi informasi dan komunikasi RPP.

\section{Langkah-langkah Menyusun RPP}

Langkah-langkah menyusun RPP adalah a) Mengisi kolom identitas, b) Menentukan alokasi waktu yang dibutuhkan untuk pertemuan yang telah ditetapkan, c) Menentukan SK, KD, dan indikator yang akan digunakan yang terdapat pada silabus yang telah disusun, d) Merumuskan indikator pencapaian berdasarkan KI, KD, e) mengidentifikasi materi ajar berdasarkan materi pokok/pembelajaran yang terdapat dalam silabus, materi ajar merupakan uraian dari materi pokok/pembelajaran, f) merumuskan langkah-langkah yang terdiri dari kegiatan awal, inti dan akhir, g) menentukan alat/bahan/sumber belajar yang digunakan, i) menyusun kriteria penilaian, lembar pengamatan, contoh soal, teknik penskoran dan kunci jawaban.

\section{Hal-hal yang Perlu Diperhatikan dalam Menyusun RPP}

Dalam penyusunan RPP perlu memperhatikan hal sebagai berikut: (a) RPP disusun untuk setiap KD yang dapat dilaksanakan dalam satu kali pertemuan atau lebih, b) tujuan pembelajaran menggambarkan proses dan hasil belajar yang harus di capai oleh peserta didik sesuai dengan kompetenrsi dasar, c) tujuan pembelajaran dapat mencakupi sejumlah indikator, atau satu tujuan pembelajaran untuk beberapa indikator, yang penting tujuan pembelajaran harus mengacu pada pencapaian indikator, d) Kegiatan pembelajaran (langkah-langkah pembelajaran) dibuat setiap pertemuan, bila dalam satu RPP terdapat 3 kali pertemuan, maka dalam RPP tersebut terdapat 3 langkah pembelajaran, e). Bila terdapat lebih dari satu pertemuan untuk indikator yang sama, tidak perlu dibuatkan langkah kegiatan yang lengkap untuk setiap pertemuannya.

Jurnal Serambi Ilmu. p-ISSN 1693-4849, e-ISSN 2549-2306 


\section{Pendampingan}

Pendampingan adalah suatu aktivitas atau kegiatan untuk mengetahui, mendengar dan membantu guru dalam mengatasi permasalahan yang dijumpai dalam upaya untuk melaksanakan kegiatan belajar mengajar yang lebih efektif sehingga dapat mencapai tujuan yang telah di tetapkan (Elvi Maliani, 2014: 36). Pengertian lain dari pendampingan adalah pantauan sejauh mana pelaksanaan penyelenggaraan sekolah, apakah sudah sesuai dengan rencana dan program yang telah ditetapkan (Kemendikbud, 2012: 6). Dengan demikian dapat disimpulkan bahwa pendampingan berarti bantuan dari pengawas sekolah atau supervisor yang sukarela mendampingi seseorang atau pun dalam kelompok untuk memenuhi kebutuhan dan pemecahan masalah dari masing-masing individu maupun kelompok. Pendampingan yang dimaksud di penelitian ini adalah pendampingan pengawas sekolah kepada guru dalam meningkatkan kompetensi menyusun Rencana Pelaksanaan Pembelajaran (RPP) kurikulum 2013.

Oleh karena itu pendampingan harus menumbuhkan keberanian pada guru untuk mencoba hal-hal baru tanpa rasa takut salah, takut gagal. Pendampingan harus menumbuhkan rasa percaya diri guru, refleksi diri, kesadaran bahwa "Saya mampu dan mau", melakukan perbaikan terus menerus walaupun tanpa pengawasan dari pengawas sekolah, kepala sekolah, maupun dari teman sejawat.

Bagi pengawas sekolah sangatlah penting memahami proses pendampingan. Pengawas sekolah memiliki peran administratif dan kekuasaan di sekolah. Mereka seyogyanya mendukung proses pendampingan dan memahami strategi dan bantuan apa yang dapat menolong guru berkembang secara profesional. (Modul USAID Prioritas, 2014: 43)

Menurut Timothy Gallwey dalam (Modul USAID Prioritas, 2014: 43) dalam apa yang dilaksanakan pendamping yang baik yaitu sebagai berikut: a. Memiliki komitmen yang tinggi, b. Memiliki sikap gender sensitive dan inklusif 
serta menerima guru yang didampingi, c. Terlatih dalam memberikan bantuan, d. Sebagai model pembelajar, e. Selalu memberikan harapan dan optimisme.

Menurut Timothy Gallwey dalam (Modul USAID Prioritas, 2014: 40) dalam fasilitas dan pendampingan ada lima langkah yang baik yaitu sebagai berikut:

a. Pendamping memberikan penghargaan, b. Terdamping melakukan sendiri refleksi kritis, c. Terdamping merencanakan sendiri perbaikan-perbaikan, d. Pendamping memberikan usul, saran atau mendiskusikan hal-hal yang dapat meningkatkan kemampuan guru dalam menyusun rencana Pelaksanaan Pembelajaran (RPP) Kurikulum 2013, e. Mengembangkan rencana tindak lanjut

Adapun beberapa manfaat pendampingan bagi guru sebagai berikut: a. Meningkatkan kinerja guru dengan semangat saling belajar, tukar pendapat dan pengalaman antara pendamping dan yang didampingi, b. Meningkatkan kinerja guru dua kali lebih cepat dibandingkan dengan hanya memberi pelatihan tanpa pendampingan, c. Memberi jalan keluar atau solusi dengan lebih fokus terhadap keterbatasan yang dimiliki, d. Membentuk pribadi yang reflektif dapat menganalisa kelebihan dan kekurangannya.

\section{METODE PENELITIAN}

\section{Setting dan Subjek Penelitian}

Penelitian Tindakan Sekolah dilaksanakan di sekolah binaan peneliti yang berada di Kota Lhokseumawe, yaitu: SMP Negeri 4 Lhokseumawe, SMP Negeri 13 Lhokseumawe, SMP Negeri Arun Lhokseumawe, SMP Swasta Islam Pase Lhokseumawe dan SMP Muhammadiyah 6 Lhokseumawe. Penelitian Tindakan Sekolah ini dilaksanakan pada semester dua tahun 2019 selama kurang lebih 4 bulan mulai Januari sampai dengan Mei 2019. Penelitian ini merupakan Penelitian Tindakan Sekolah (PTS) dalam bentuk siklus yang terdiri dari tahap perencanaan, tahap pelaksanaan tindakan, tahap observasi dan tahap refleksi yang dilakukan dalam dua siklus. Subjek penelitian adalah guru-guru binaan peneliti yang berada di SMP Kota Lhokseumawe sebanyak 20 orang guru.

Jurnal Serambi Ilmu. p-ISSN 1693-4849, e-ISSN 2549-2306 


\section{Teknik Pengumpulan Data}

Teknik pengumpulan data dari penelitian tindakan sekolah ini adalah melalui data kualitatif yang diperoleh dari wawancara, observasi dan diskusi. Wawancara dipergunakan untuk mendapatkan data atau informasi tentang pemahaman guru terhadap RPP Kurikulum 2013. Observasi dipergunakan untuk mengumpulkan data dan mengetahui kompetensi guru dalam menyusun Rencana Pelaksanaan Pembelajaran (RPP) Kurikulum 2013 dengan lengkap. Diskusi dilakukan antara peneliti dengan guru.

\section{Pengolahan Dan Analisis Data}

Analisa data yang digunakan dalam penelitian ini adalah analisa data kualitatif yang bersumber dari lembar wawancara dan pengamatan. Melalui analisa data ini, dapat diketahui ada tidaknya kompetensi guru dalam menyusun Rencana Pelaksanaan Pembelajaran (RPP) Kurikulum 2013 dengan lengkap melalui pemberian pembinaan yang merupakan fokus dari penelitian tindakan sekolah ini.

Adapun kegiatan-kegiatan yang dilakukan dalam menganalisis dan mengolah data sebagai berikut: 1) Editing yaitu mengecek semua data yang dikumpulkan. 2)Tabulasi yaitu proses pembuatan tabel. 3)Mempersentasekan data yang telah dihitung perkategori dengan menggunakan rumus persentase. 4)Menyimpulkan hasil penelitian, sehingga diperoleh deskripsi tentang tingkat kompetensi guru dalam menyusun Rencana Pelaksanaan Pembelajaran (RPP) Kurikulum 2013.

\section{HASIL PENELITIAN DAN PEMBAHASAN}

\section{Deskripsi Kondisi Awal}

Dari hasil wawancara terhadap delapan orang guru, peneliti memperoleh informasi bahwa semua guru (dua puluh orang) belum tahu kerangka penyusunan RPP Kurikulum 2013, hanya sekolah yang memiliki dokumen standar proses (satu buah), hanya dua orang guru yang pernah mengikuti pelatihan pengembangan RPP Kurikulum 2013, umumnya guru mengadopsi dan mengadaptasi RPP Kurikulum 2013, kebanyakan guru tidak tahu dan tidak paham menyusun RPP Kurikulum 2013 secara lengkap, mereka setuju bahwa guru harus menggunakan RPP Kurikulum 2013 dalam 
melaksanakan proses pembelajaran yang dapat dijadikan acuan/pedoman dalam proses pembelajaran. Selain itu, kebanyakan guru belum tahu dengan komponen-komponen RPP Kurikulum 2013 secara lengkap. Berdasarkan hasil observasi peneliti terhadap delapan RPP Kurikulum 2013 yang disusun guru (khusus pada siklus I), diperoleh informasi/data bahwa masih ada guru yang tidak melengkapi RPP-nya dengan komponen dan sub-subkomponen RPP tertentu, misalnya komponen indikator dan penilaian hasil belajar (pedoman penskoran dan kunci jawaban). Rumusan kegiatan siswa pada komponen langkah-langkah kegiatan pembelajaran masih kurang tajam, interaktif, inspiratif, menantang, dan sistematis.

\section{Hasil Penelitian}

Deskripsi Hasil Siklus I, Siklus pertama terdiri dari empat tahap yakni: (1) perencanaan, (2) pelaksanaan, (3) observasi, dan (4) refleksi seperti berikut ini. Perencanaan (Planning) meliputi beberapa kegiatan : Membuat lembar wawancara dan format lembar pedoman penilaian Rencana Pelaksanaan Pembelajaran (RPP) Kurikulum 2013. a. Sosialisasi kepada guru. b. Melaksanakan observasi Rencana Pelaksanaan Pembelajaran (RPP) Kurikulum 2013 yang di susun guru. c, Melakukan pendampingan dan d. Melakukan refleksi.

Pelaksanaan (Acting). Berdasarkan hasil wawancara dan observasi sebelum tindakan, pada saat awal siklus pertama indikator pencapaian hasil dari setiap komponen RPP belum sesuai/tercapai seperti rencana/keinginan peneliti. Hal itu dibuktikan dengan masih adanya komponen RPP yang belum disusun oleh guru. Sembilan komponen RPP Kurikulum 2013 yakni: 1) identitas, 2) alokasi waktu, 3) kompetensi inti, 4) kompetensi dasar, 5) indikator pencapaian kompetensi, 6) tujuan pembelajaran, 7) materi ajar, 8) metode pembelajaran, 9) langkah-langkah kegiatan pembelajaran, 10) sumber belajar, 11) penilaiaan hasil belajar (soal, pedoman penskoran, dan kunci jawaban).

Selanjutnya dalam pembinaan peneliti meminta guru-guru untuk membuat dan menyusun RPP sesuai dengan penjelasan yang telah dijabarkan oleh peneliti. Peneliti mengamati guru-guru dalam menyusun RPP dan melakukan revisi atau perbaikan terhadap RPP yang disusun guru-guru bila terdapat kekurangan.

Observasi

Jurnal Serambi Ilmu. p-ISSN 1693-4849, e-ISSN 2549-2306

Journal of Scientific Information and Educational Creativity 
Observasi pada siklus I (pertama) terhadap 20 orang guru, menunjukan bahwa semua guru telah menyusun RPP, namun masih terdapat guru yang belum sempurna dalam menyusun komponen RPP. Hasil observasi dapat dilihat pada tabel berikut.

Tabel Hasil Observasi terhadap Guru Siklus I

\begin{tabular}{|c|l|c|c|}
\hline No & \multicolumn{1}{|c|}{ Guru } & Jumlah & $(\%)$ \\
\hline 1 & Responden A & 30 & 68,18 \\
\hline 2 & Responden B & 30 & 68,18 \\
\hline 3 & Responden C & 29 & 65,91 \\
\hline 4 & Responden D & 30 & 68,18 \\
\hline 5 & Responden E & 31 & 70,45 \\
\hline 6 & Responden F & 29 & 65,91 \\
\hline 7 & Responden G & 28 & 63,64 \\
\hline 8 & Responden H & 34 & 77,27 \\
\hline 9 & Responden I & 29 & 65,91 \\
\hline 10 & Responden J & 28 & 63,64 \\
\hline 11 & Responden K & 31 & 70,45 \\
\hline 12 & Responden L & 35 & 79,55 \\
\hline 13 & Responden M & 33 & 75 \\
\hline 14 & Responden N & 34 & 77,27 \\
\hline 15 & Responden O & 26 & 59,09 \\
\hline 16 & Responden P & 26 & 59,09 \\
\hline 17 & Responden Q & 28 & 63,64 \\
\hline 18 & Responden R & 28 & 63,64 \\
\hline 19 & Responden S & 34 & 77,27 \\
\hline 20 & Responden T & 31 & 70,45 \\
\hline \multicolumn{2}{|c|}{ Jumlah } & 684 & \\
\hline \multicolumn{2}{|c|}{ Rata-rata (\%) } & \\
\hline & & & \\
\hline
\end{tabular}

Berdasarkan tabel diatas diketahui bahwa hasil observasi terhadap 20 orang guru belum mencapai indikator pencapaian hasil yang diharapkan peneliti. Hal ini terlihat jelas dari hasil pengamatan, dimana terdapat guru yang belum lengkap dalam menyusun RPP. Sehingga rata-rata persentase pengamatan belum tercapai. Untuk lebih jelas persentase dari 11 komponen RPP hasil observasi terrhadap 20 orang guru dapat dilihat pada tabel 4.2 di bawah ini. 
Tabel Persentase Hasil Observasi Siklus I

\begin{tabular}{|c|l|c|}
\hline No & \multicolumn{1}{|c|}{ Komponen } & Siklus I \\
\hline 1 & Mencantumkan Identitas & $92,5 \%$ \\
\hline 2 & Mencantumkan Alokasi waktu & $81,25 \%$ \\
\hline 3 & Mencantumkan KI & $71,25 \%$ \\
\hline 4 & Mencantumkan KD & $67,5 \%$ \\
\hline 5 & Mencantumkan Indikator & $62,5 \%$ \\
\hline 6 & Mencantumkan Tujuan Pembelajaran & $63,75 \%$ \\
\hline 7 & Mencantumkan Materi & $65 \%$ \\
\hline 8 & Mencantumkan Metode Pembelajaran & $65 \%$ \\
\hline 9 & Mencantumkan Langkah-langkah kegiatan pembelajaran & $60 \%$ \\
\hline 10 & Mencantumkan Sumber Belajar & $66,25 \%$ \\
\hline 11 & Mencantumkan Penilaian & $60 \%$ \\
\hline \multicolumn{2}{r|}{ Rata-rata Total Persentase } & $68,64 \%$ \\
\hline
\end{tabular}

Berdasarkan tabel diketahui bahwa persentase terhadap 11 komponen komponen RPP sudah ada yang mencapai indikator diharapkan yaitu komponen alokasi waktu. Kemudian ada beberapa komponen yang sudah mendekati indikator pencapaian hasil. Seperti pada komponen identitas mata pelajaran dengan persentase $92,5 \%$ dari $100 \%$ dan komponen sumber belajar dengan persentase $66,25 \%$ dari $75 \%$ yang diharapkan. Sedangkan untuk komponen yang lainnya masih belum mencapai indikator yang diharapkan. Persentase secara keseluruhan adalah 68,64\% dari 85\% yang diharapkan. Sehingga dapat disimpulkan hasil observasi pada siklus I belum mencapai indikator keberhasilan.

Refleksi. Berdasarkan hasil observasi ditemukan berbagai kelemahan yang harus diperbaiki pada siklus berikutnya. Beberapa kelemahan tersebut adalah sebagai berikut: a. Satu orang tidak melengkapinya dengan teknik dan bentuk instrumen, b. Satu orang tidak melengkapinya dengan teknik, bentuk instumen, soal, pedoman penskoran, dan kunci jawaban, c. Dua orang tidak melengkapinya dengan teknik, pedoman penskoran, dan kunci jawaban, d. Satu orang tidak melengkapinya dengan soal, pedoman penskoran, dan kunci jawaban, e. Satu orang tidak melengkapinya dengan pedoman penskoran dan kunci jawaban. Selanjutnya mereka dibimbing dan disarankan untuk melengkapinya.

Berdasarkan kelemahan tersebut, maka pada siklus berikutnya peneliti harus memberikan pembinaan lebih lanjut agar hasil yang diharapkan bisa tercapai sesuai dengan indikator pencapain hasil. 
Hasil Siklus II, Siklus II (kedua) ini merupakan perbaikan dari siklus I (pertama). Pada siklus II, peneliti melakukan perbaikan terhadap kelemahan yang terhadap siklus I dengan memberikan supervisi atau pembinaan terhadap 20 guru yang menjadi subjek dalam penelitian ini. Pelaksanaan siklus II (kedua) sama dengan siklus I (pertama) yang terdiri dari empat tahap yakni: (1) perencanaan, (2) pelaksanaan, (3) observasi, dan (4) refleksi. Berikut penjelasan dari setiap tahapan tersebut.

Perencanaan (Planning) meliputi : a. Peneliti membuat format lembar pedoman penilaian Rencana Pelaksanaan Pembelajaran (RPP) Kurikulum 2013, b. Melaksanakan observasi Rencana Pelaksanaan Pembelajaran (RPP) Kurikulum 2013 yang di susun guru, c. Melakukan pendampingan, d. Peneliti dan guru melakukan refleksi dengan melakukan perbaikan atau revisi penyusunan RPP yang disusun guru, e. Peneliti membuat format rekapitulasi hasil penyusunan RPP siklus II, f. Peneliti membuat format rekapitulasi hasil penyusunan RPP dari siklus I ke siklus II.

Pelaksanaan (Acting), Pelaksanaan pada siklus kedua ini peneliti malaksanakan pembinaan penyusunan RPP dengan menjelaskan kembali 11 komponen RPP. Kemudian peneliti melakukan pengamatan terhadap RPP yang disusun oleh para guru. Peneliti bersama guru melakukan revisi bila RPP masih belum sempurna.

Observasi, Hasil observasi pada siklus II (kedua) terhadap 24 (dua puluh empat) orang guru diketahui bahwa semuanya menyusun RPP. Hasil observasi dapat di lihat pada tabel di bawah ini.

Tabel Hasil Observasi terhadap Guru Siklus II

\begin{tabular}{|c|l|c|c|}
\hline No & \multicolumn{1}{|c|}{ Guru } & Jumlah & $(\%)$ \\
\hline 1 & Responden A & 38 & 86,36 \\
\hline 2 & Responden B & 36 & 81,82 \\
\hline 3 & Responden C & 35 & 79,55 \\
\hline 4 & Responden D & 37 & 84,09 \\
\hline 5 & Responden E & 35 & 79,55 \\
\hline 6 & Responden F & 35 & 79,55 \\
\hline 7 & Responden G & 35 & 79,55 \\
\hline 8 & Responden H & 41 & 93,18 \\
\hline 9 & Responden I & 35 & 79,55 \\
\hline 10 & Responden J & 36 & 81,82 \\
\hline 11 & Responden K & 38 & 86,36 \\
\hline
\end{tabular}




\begin{tabular}{|c|c|c|c|}
\hline 12 & Responden L & 42 & 95,45 \\
\hline 13 & Responden M & 39 & 88,64 \\
\hline 14 & Responden N & 41 & 93,18 \\
\hline 15 & Responden $\mathrm{O}$ & 35 & 79,55 \\
\hline 16 & Responden $\mathrm{P}$ & 36 & 81,82 \\
\hline 17 & Responden Q & 37 & 84,09 \\
\hline 18 & Responden $\mathrm{R}$ & 35 & 79,55 \\
\hline 19 & Responden $\mathrm{S}$ & 43 & 97,73 \\
\hline 20 & Responden $\mathrm{T}$ & 40 & 90,91 \\
\hline \multicolumn{2}{|c|}{ Jumlah } & 749 & \\
\hline & Rata-rata (\%) & $85,11 \%$ & \\
\hline
\end{tabular}

Berdasarkan tabel diatas diketahui nilai para guru secara individu telah mengalami peningkatan dibandingkan dengan siklus I (pertama). Bahkan beberapa guru mengalami peningkatan yang signifikan. Hal ini menunjukkan perbaikan yang dilakukan peneliti berhasil. Untuk melihat persentase hasil observasi lebih jelas dapat dilihat pada tabel di bawah ini.

Tabel Persentase Hasil Observasi Sikulus II

\begin{tabular}{|c|l|c|}
\hline No & \multicolumn{1}{|c|}{ Komponen } & Siklus II \\
\hline 1 & Mencantumkan Identitas & $100 \%$ \\
\hline 2 & Mencantumkan Alokasi waktu & $100 \%$ \\
\hline 3 & Mencantumkan KI & $86,25 \%$ \\
\hline 4 & Mencantumkan KD & $86,25 \%$ \\
\hline 5 & Mencantumkan Indikator & $86,25 \%$ \\
\hline 6 & Mencantumkan Tujuan Pembelajaran & $83,75 \%$ \\
\hline 7 & Mencantumkan Materi & $80 \%$ \\
\hline 8 & Mencantumkan Metode Pembelajaran & $77,50 \%$ \\
\hline 9 & Mencantumkan Langkah-langkah kegiatan pembelajaran & $78 \%$ \\
\hline 10 & Mencantumkan Sumber Belajar & $75 \%$ \\
\hline 11 & Mencantumkan Penilaian & $84 \%$ \\
\hline \multicolumn{2}{|r|}{ Rata-rata total persentase } & $85,11 \%$ \\
\hline
\end{tabular}

Berdasarkan tabel di atas dapat dilihat persentase setiap komponen RPP mengalami peningkatan dibandingkan siklus I (pertama). Beberapa diantaranya mengalami peningkatan yang signifikan. Rata-rata total persentasenya adalah $85,11 \%$, sehingga dapat di usulkan untuk siklus II telah mencapai indikator pencapaian hasil yang diharapkan yaitu 85\%. Untuk melihat persentase peningkatan dari siklus I (pertama) ke siklus II (kedua) dapat dilihat pada tabel di bawah ini: 
Tabel Persentase Peningkatan Penyusunan RPP Dari Siklus I Ke Siklus II

\begin{tabular}{|c|c|c|c|c|}
\hline \multirow{2}{*}{ No } & \multirow{2}{*}{ Komponen } & \multicolumn{2}{|c|}{ Persentase } & \multirow{2}{*}{$\begin{array}{l}\text { Persentase } \\
\text { peningkatan }\end{array}$} \\
\hline & & Siklus I & Siklus II & \\
\hline 1 & Mencantumkan Identitas & $92,5 \%$ & $100 \%$ & $7,50 \%$ \\
\hline 2 & Mencantumkan Alokasi waktu & $81,25 \%$ & $100 \%$ & $18,75 \%$ \\
\hline 3 & Mencantumkan KI & $71,25 \%$ & $86,25 \%$ & $15 \%$ \\
\hline 4 & Mencantumkan KD & $67,5 \%$ & $86,25 \%$ & $18,75 \%$ \\
\hline 5 & Mencantumkan Indikator & $62,5 \%$ & $86,25 \%$ & $23,75 \%$ \\
\hline 6 & Mencantumkan Tujuan Pembelajaran & $63,75 \%$ & $83,75 \%$ & $20 \%$ \\
\hline 7 & Mencantumkan Materi & $65 \%$ & $80 \%$ & $15 \%$ \\
\hline 8 & Mencantumkan Metode Pembelajaran & $65 \%$ & $77,50 \%$ & $12,5 \%$ \\
\hline 9 & $\begin{array}{l}\text { Mencantumkan Langkah-langkah kegiatan } \\
\text { pembelajaran }\end{array}$ & $60 \%$ & $77,5 \%$ & $17,5 \%$ \\
\hline 10 & Mencantumkan Sumber Belajar & $66,25 \%$ & $75 \%$ & $8,75 \%$ \\
\hline 11 & Mencantumkan Penilaian & $60 \%$ & $83,75 \%$ & $23,75 \%$ \\
\hline \multicolumn{2}{|c|}{ Rata-rata total persentase } & $68,64 \%$ & $85,11 \%$ & $16,47 \%$ \\
\hline
\end{tabular}

Tabel di atas menunjukkan peningkatan penyusunan RPP para guru. Bila dilihat indikator pencapaian hasil yang diharapkan, setiap komponen telah mencapai kompetensi yang diharapkan. Rata-rata total persentase peningkatan dari siklus I ke siklus II adalah $16,47 \%$.

Refleksi

Berdasarkan pelaksanaan tindakkan yang dilakukan dan hasil observasi, menunjukkan bahwa indikator pencapaian hasil yang diharapkan peneliti telah tercapai. Kelemahan yang terjadi pada siklus I telah diperbaiki. emuanya menyusun RPP Kurikulum 2013, tapi masih ada guru yang keliru dalam menentukan kegiatan siswa dalam langkah-langkah kegiatan pembelajaran dan metode pembelajaran, serta tidak memilah/ menguraikan materi pembelajaran dalam sub-sub materi. Untuk komponen penilaian hasil belajar, dapat dikemukakan sebagai berikut, a. Satu orang keliru dalam menentukan teknik dan bentuk instrumennya, b. Satu orang keliru dalam menentukan bentuk instrumen berdasarkan teknik penilaian yang dipilih, c. Dua orang kurang jelas dalam menentukan pedoman penskoran, d. Satu orang tidak menuliskan rumus perolehan nilai siswa. Selanjutnya mereka dibimbing dan disarankan untuk melengkapinya. 


\section{KESIMPULAN}

Berdasarkan pelaksanaan penelitian yang sudah dilakukan dan hasil yang didapat diketahui bahwasanya dapat ditarik kesimpulan sebagai berikut:

Pendampingan dapat meningkatkan motivasi guru dalam menyusun RPP Kurikulum 2013 dengan lengkap. Guru menunjukkan keseriusan dalam memahami dan menyusun RPP Kurikulum 2013 apalagi setelah mendapatkan bimbingan pengembangan/penyusunan RPP dari peneliti. Informasi ini peneliti peroleh dari hasil pengamatan pada saat mengadakan wawancara dan bimbingan pengembangan/ penyusunan RPP Kurikulum 2013 kepada para guru.

Pendampingan dapat meningkatkan kompetensi guru dalam menyusun RPP Kurikulum 2013. Hal itu dapat dibuktikan dari hasil observasi/pengamatan yang memperlihatkan bahwa terjadi peningkatan kompetensi guru dalam menyusun RPP dari siklus ke siklus. Pada siklus pertama persentase komponen RPP adalah 68,64\% dan pada siklus kedua adalah $85,11 \%$. Peningkatan persentase dari siklus pertama ke siklus kedua adalah $16,47 \%$.

\section{DAFTAR PUSTAKA}

- Departemen Pendidikan Nasional. (2005). Peraturan Menteri Pendidikan Nasional Republik Indonesia Nomor 19 Tahun 2005 tentang Standar Nasional Pendidikan. Jakarta: Depdiknas.

- Departemen Pendidikan Nasional. (1996). SK Menpan Nomor 118 tentang jabatan fungsional pengawas dan angka kreditnya. Depdiknas: Jakarta.

- Depdiknas. (2003). UU RI No. 20 Tahun 2003 tentang Sistem Pendidikan Nasional. Jakarta: Depdiknas.

- Depdiknas. (2004). Standar Kompetensi Guru Sekolah Dasar. Jakarta: Depdiknas.

- Depdiknas. (2005). UU RI No. 14 Tahun 2005 tentang Guru dan Dosen. Jakarta: Depdiknas.

- Fahmi, C. N., Nurliza, E., Murniati, A. R., \& Usman, N. (2018). Pelaksanaan Supervisi Akademik Dalam Meningkatkan Kompetensi Guru Sekolah Dasar. JURNAL SERAMBI ILMU, 30(2), 104-119 
- Kemendikbud. (2012). Panduan Integrasi Pendidikan Karakter Pembelajaran IPA DI Sekolah Dasar. Jakarta.

- Jailani, J., Abubakar, A. and Anwar, A., 2018. Implementasi Pendekatan Science Technology Society (Sts) Pada Materi Pokok Lingkungan Hidup Sebagai Upaya Peningkatanlife Skill Siswa. JURNAL SERAMBI ILMU, 30(2), pp.132-142.

- Kemendikbud. (2013c). Instrumen Pendampingan Implementasi Kurikulum 2013. Jakarta: Kementerian Pendidikan dan Kebudayaan Direktorat Jenderal Pendidikan Dasar Direktorat Pembinaan SMP.

- Kurniawati Eni. (2009). Pengembangan Bahan Ajar Bahasa Dan Sastra Indonesia Dengan Pendekatan Tematis. Tesis. Surakarta: Program Pascasarjana Universitas Sebelas Maret.

- Permendikbud 103 tahun 2014 tentang standar penilaian untuk Satuan Pendidikan Dasar dan Menengah. Jakarta.

- Pidarta, Made. (2003). Pemikiran Tentang Supervisi Pendidikan. Jakarta: Bumi Aksara.

- Sudjana, Nana. (2009). Standar Kompetensi Pengawas Dimensi dan Indikator. Jakarta: Binamitra Publishing.

- Suparlan. (2005). Menjadi Guru Efektif. Yogyakarta: Hikayat Publishing.

- USAID. 2014. USAID PRIORITAS: Mengutamakan Pembaharuan, Inovasi,dan Kesempatan bagi Guru, Tenaga Kependidikan dan Siswa. Indonesia: RTI International.

- Zainuddin, Z. (2018). Peranan Pedamping Wilayah Dalam Peningkatan Ketrampilan Kepala Sekolah Dalam Melaksanakan Supervisi Pembelajaran. JURNAL SERAMBI ILMU, 30(2), 154-181. 